Supporting Information

\title{
Elucidating Film Loss and the Role of Hydrogen Bonding of Adsorbed Redox Enzymes by Electrochemical Quartz Crystal Microbalance Analysis
}

Vivek M. Badiani,${ }^{\dagger,+}$ Samuel J. Cobb,${ }^{\dagger}$ Andreas Wagner,${ }^{\dagger}$ Ana Rita Oliveira, ${ }^{\S}$ Sónia Zacarias,, Inês A. C. Pereira, ${ }^{\S}$ and Erwin Reisner ${ }^{\dagger, *}$

$\dagger$ Yusuf Hamied Department of Chemistry, University of Cambridge, Lensfield Road, Cambridge, CB2 1EW, U.K.

\$ Cambridge Graphene Centre, University of Cambridge, Cambridge, CB3 OFA, U.K.

$\S$ Instituto de Tecnologia Química e Biológica António Xavier (ITQB NOVA), Universidade NOVA de Lisboa, Av. da República, 2780-157 Oeiras, Portugal.

*To whom correspondence may be addressed. Email: reisner@ch.cam.ac.uk 


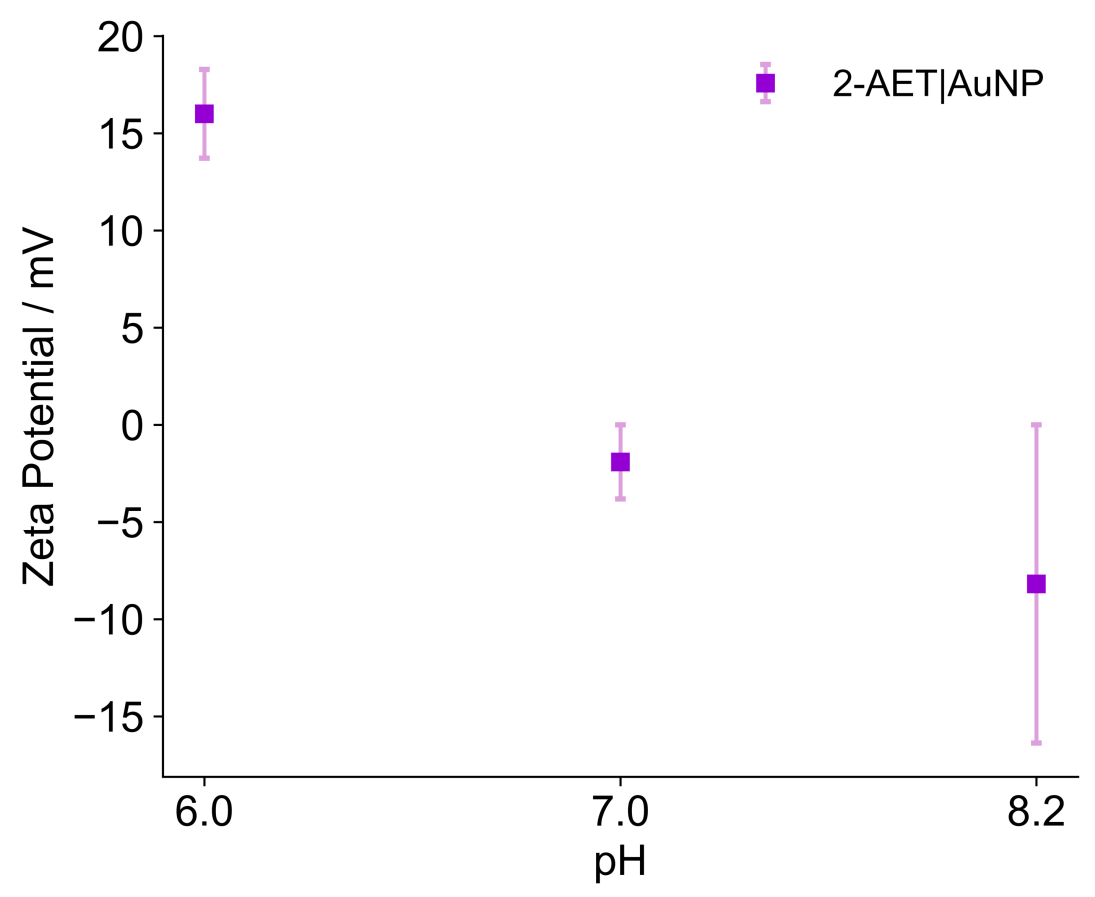

Figure S1. Determination of the electrostatic charge of 2-AET $\mid$ AuNPs vs $\mathrm{pH}$. The electrostatic charge of the ligand was found to be around $+15 \mathrm{mV}$ at $\mathrm{pH} 6$, and drastically decreases to neutral and negative at $\mathrm{pH} 7.0$ and 8.2. This is however, not to be taken as like-for-like with a planar gold surface, as surface topology is expected to shift $\mathrm{pK}_{\mathrm{a}}$ values by a few units (Langmuir 2002, 18 (6), 2239-2245). 

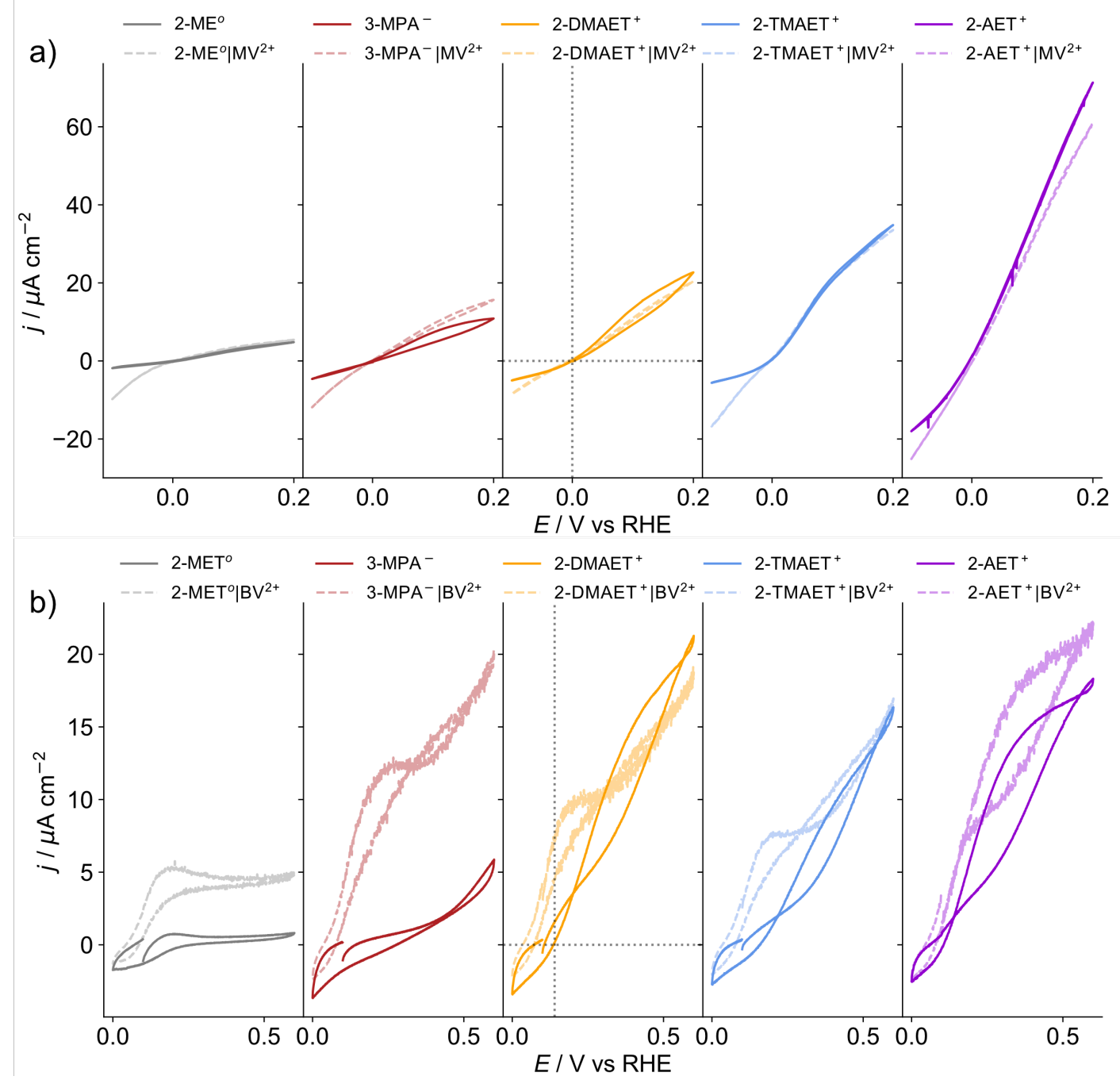

Figure S2. Representative protein film voltammograms of (a) $\mathrm{H}_{2}$ ase and (b) FDH on each SAMmodified $\mathrm{Au}$ electrode. The black dotted line on 2 -DMAET ${ }^{+}$represents the $E^{0^{\prime}}$ of the $\mathrm{H}^{+} / \mathrm{H}_{2}$ or $\mathrm{CO}_{2} / \mathrm{HCO}_{2}{ }^{-}$couple. The FDH MET protein film voltammograms (dashed lines) are slightly shifted to negative potentials possibly due to the enhanced electron transfer kinetics of the enzyme during MET. Conditions: $\mathrm{MES} / \mathrm{KCl}\left(50 \mathrm{mM} / 50 \mathrm{mM}, \mathrm{pH}\right.$ 6) 1 atm $\mathrm{H}_{2}$ for $\mathrm{H}_{2}$ ase (10 pmol), HEPES/KCl/formate ( $50 \mathrm{mM} / 50 \mathrm{mM} / 20 \mathrm{mM}, \mathrm{pH}$ 8) for FDH (40 pmol) activated by incubation with 1,4-dithiothreitol (DTT, $50 \mathrm{mM}$ ). $v=5 \mathrm{mV} \mathrm{s}^{-1}, \omega=2000 \mathrm{rpm}, 25^{\circ} \mathrm{C}$. 


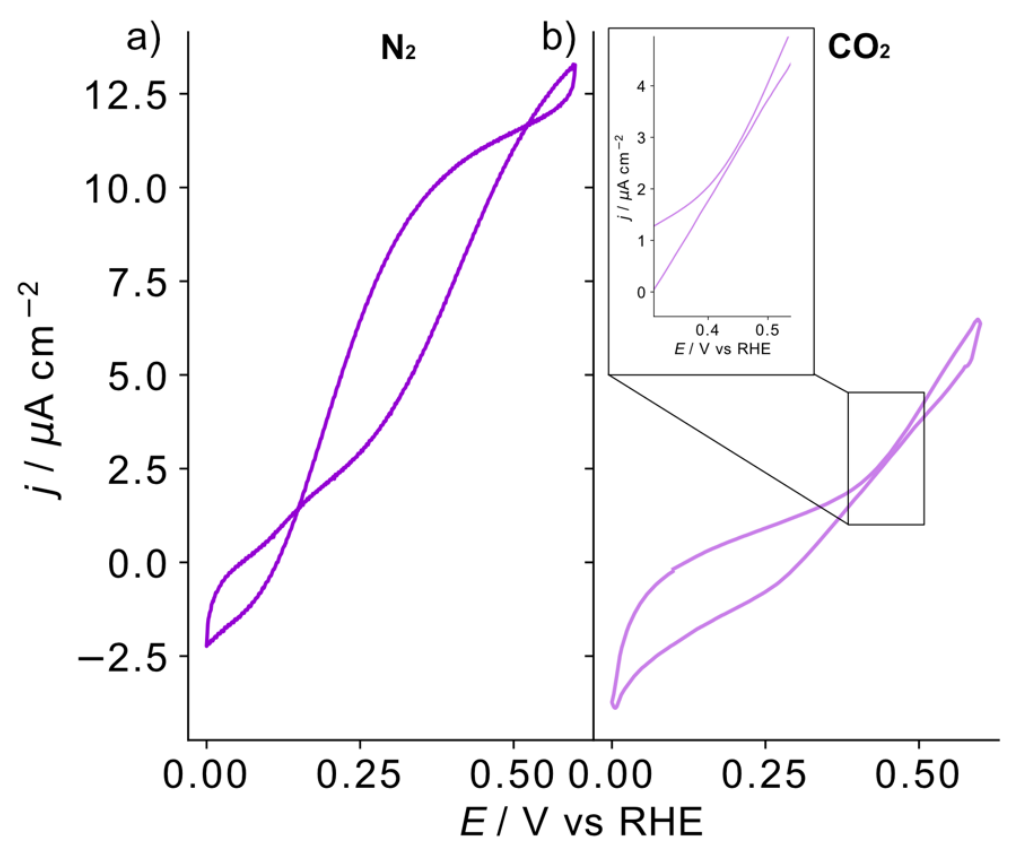

Figure S3. Representative protein film voltammograms of FDH on a $2-\mathrm{AET}^{+} \mid \mathrm{Au}$ electrode under (a) $\mathrm{N}_{2}$ and (b) $\mathrm{CO}_{2}$. Conditions: HEPES/KCl/formate $(50 \mathrm{mM} / 50 \mathrm{mM} / 20 \mathrm{mM}, \mathrm{pH} 8), 1$ atm $\mathrm{N}_{2}$ or $1 \mathrm{~atm} \mathrm{CO}_{2}, \mathrm{FDH}(40 \mathrm{pmol})$ activated by incubation with 1,4-dithiothreitol (DTT, $\left.50 \mathrm{mM}\right) . v=5$ $\mathrm{mV} \mathrm{s}^{-1}, \omega=2000 \mathrm{rpm}, 25^{\circ} \mathrm{C}$. 


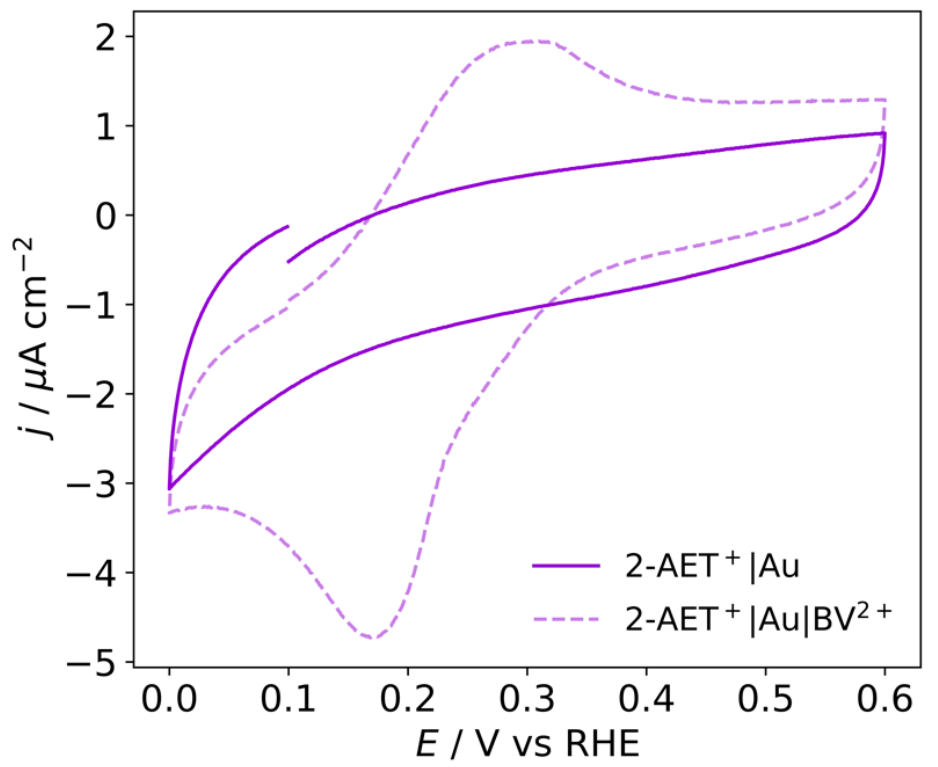

Figure S4. A cyclic voltammogram of an enzyme-free 2-AET ${ }^{+}$-modified Au electrode both in the absence (solid line) and presence (dashed line) of $250 \mu \mathrm{M} \mathrm{BV}^{2+}$. Conditions: $\mathrm{HEPES} / \mathrm{KCl} /$ formate $(50 \mathrm{mM} / 50 \mathrm{mM} / 20 \mathrm{mM}, \mathrm{pH} 8), v=5 \mathrm{mV} \mathrm{s}^{-1}, \omega=2000 \mathrm{rpm}, 25^{\circ} \mathrm{C}$.
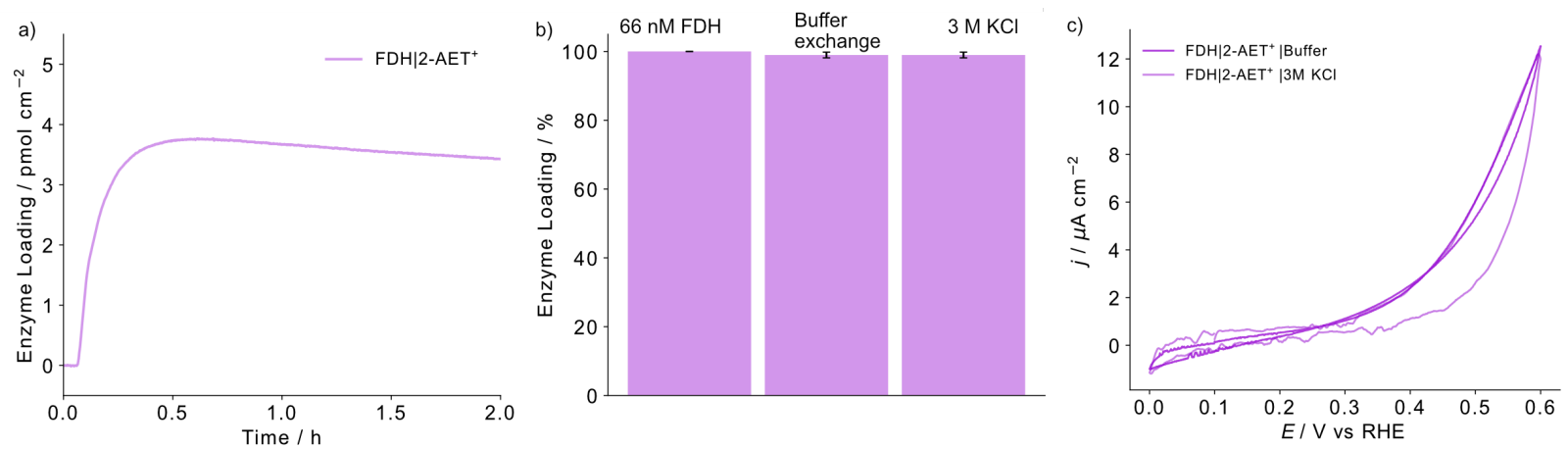

Figure S5. (a) QCM profile for the immobilization of FDH on a 2-AET-modified Au sensor. (b) Desorption profiles of FDH on the SAM-modified Au sensor after a buffer exchange followed by exposure to $3 \mathrm{M} \mathrm{KCl}$. (c) PFV responses of FDH on the SAM-modified sensor after buffer exchange and $3 \mathrm{M} \mathrm{KCl}$. Loading of FDH in MES/KCl (50 mM/50 mM, pH 6), FDH (66 nM), PFV of FDH in HEPES/KCl/formate $(50 \mathrm{mM} / 50 \mathrm{mM} / 20 \mathrm{mM}$, pH 8), DTT $(50 \mathrm{mM})$, flow rate $=0.141$ $\mathrm{mL} \min ^{-1}, 25^{\circ} \mathrm{C}$. 

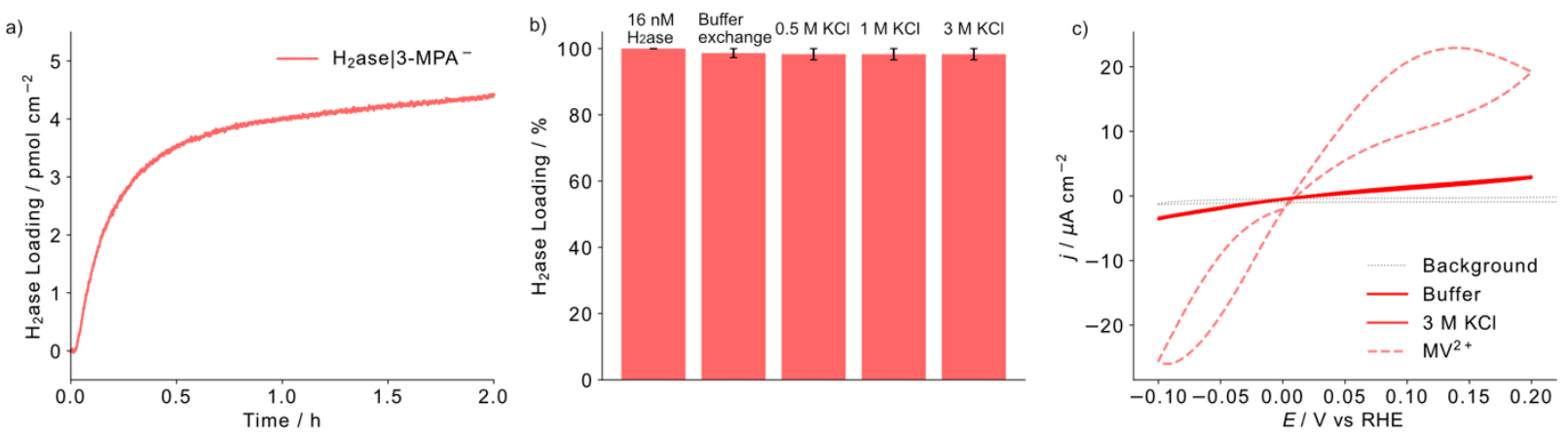

Figure S6. E-QCM study of $\mathrm{H}_{2}$ ase on (a) 3-MPA ${ }^{-}$(b) desorption studies of the $\mathrm{H}_{2}$ ase $\left|3-\mathrm{MPA}^{-}\right| \mathrm{Au}$ QCM chip and (c) the PFV responses showing the remaining electrochemical activity of $\mathrm{H}_{2}$ ase after the buffer and $3 \mathrm{M} \mathrm{KCl}$ washing step and after the addition of $250 \mu \mathrm{M} \mathrm{MV}^{2+}$. MES/KCl (50 $\mathrm{mM} / 50 \mathrm{mM}, \mathrm{pH} 6), 1 \mathrm{~atm} \mathrm{H}_{2}, 25^{\circ} \mathrm{C}$.
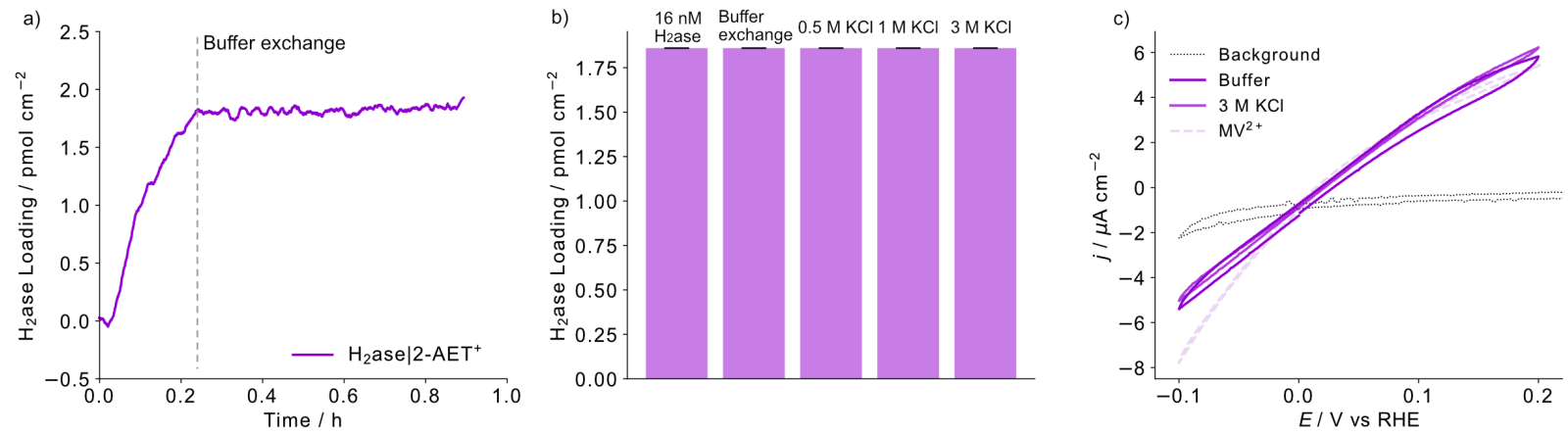

Figure S7. E-QCM study of half loading of $\mathrm{H}_{2}$ ase on (a) $2-\mathrm{AET}^{+}$, where the $\mathrm{H}_{2}$ ase solution is switched to buffer only after 20 mins to prevent electrode saturation and the loading experiment stopped after $1 \mathrm{~h},(\mathrm{~b})$ desorption studies of the half-loaded 2-AET ${ }^{+} \mid \mathrm{Au}$ QCM chip and (c) the PFV responses showing the remaining electrochemical activity of $\mathrm{H}_{2}$ ase after the buffer and $3 \mathrm{M} \mathrm{KCl}$ washing step and after the addition of $250 \mu \mathrm{M} \mathrm{MV}^{2+}$. $\mathrm{MES} / \mathrm{KCl}\left(50 \mathrm{mM} / 50 \mathrm{mM}, \mathrm{pH}\right.$ 6), 1 atm $\mathrm{H}_{2}$, $25{ }^{\circ} \mathrm{C}$. 

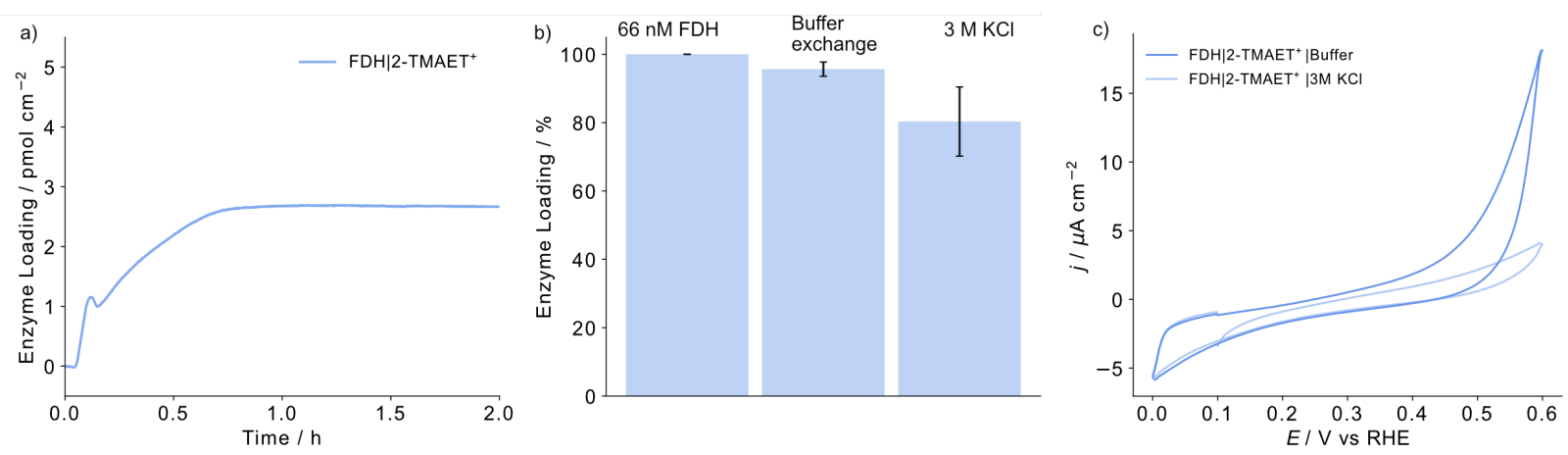

Figure S8. (a) QCM profile for the immobilization of FDH on a 2-TMAET ${ }^{+}$-modified Au sensor.

(b) Desorption profiles of FDH on the SAM-modified Au sensor after a buffer exchange followed by exposure to $3 \mathrm{M} \mathrm{KCl}$. (c) PFV responses of FDH on the SAM-modified sensor after buffer exchange and $3 \mathrm{M} \mathrm{KCl}$. Loading of FDH in MES/KCl (50 mM/50 mM, pH 6), FDH (66 nM), PFV of FDH in HEPES/KCl/formate $(50 \mathrm{mM} / 50 \mathrm{mM} / 20 \mathrm{mM}$, pH 8), DTT $(50 \mathrm{mM})$, flow rate $=0.141$ $\mathrm{mL} \min ^{-1}, 25^{\circ} \mathrm{C}$.
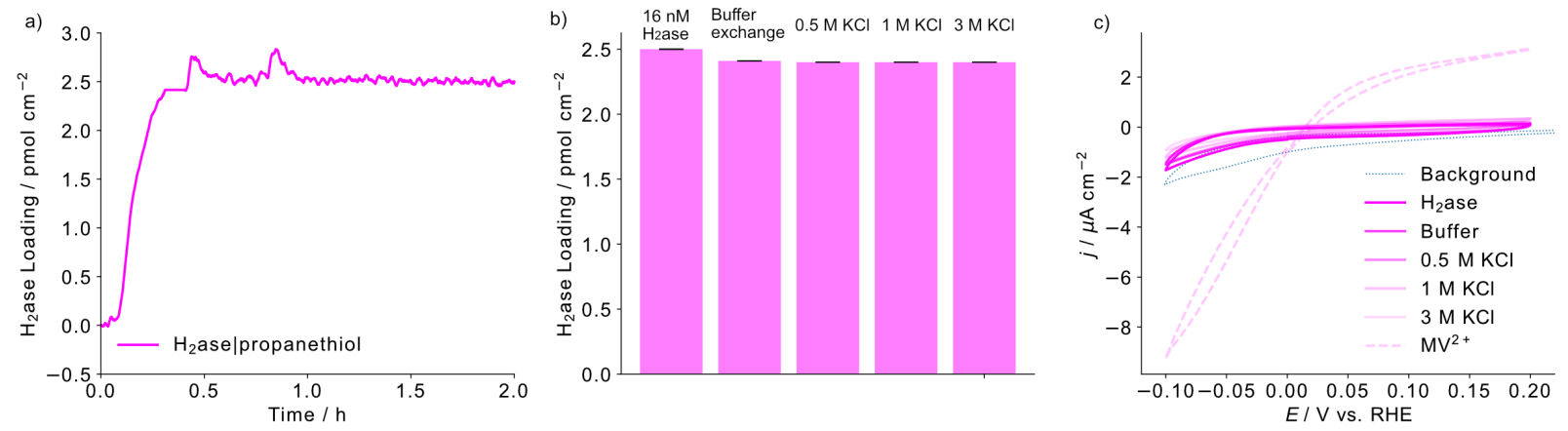

Figure S9. E-QCM study of $\mathrm{H}_{2}$ ase on propanethiol-modified $\mathrm{Au}$ where (a) shows the loading plateauing at ca. $2.5 \mathrm{pmol} \mathrm{cm}$, (b) shows the desorption studies of $\mathrm{H}_{2}$ ase loaded on propanethiol|Au, with no desorption at $3 \mathrm{M} \mathrm{KCl}$ (c) the PFVs showing the low DET electrochemical activity of $\mathrm{H}_{2}$ ase after each $\mathrm{KCl}$ washing step, followed by the MET (dashed line) after addition of $\mathrm{MV}^{2+}(250 \mu \mathrm{M})$ into the flowing electrolyte to confirm the presence of $\mathrm{H}_{2}$ ase on the electrode. $\mathrm{MES} / \mathrm{KCl}(50 \mathrm{mM} / 50 \mathrm{mM}, \mathrm{pH} 6), 1$ atm $\mathrm{H}_{2}, 25{ }^{\circ} \mathrm{C}$. 


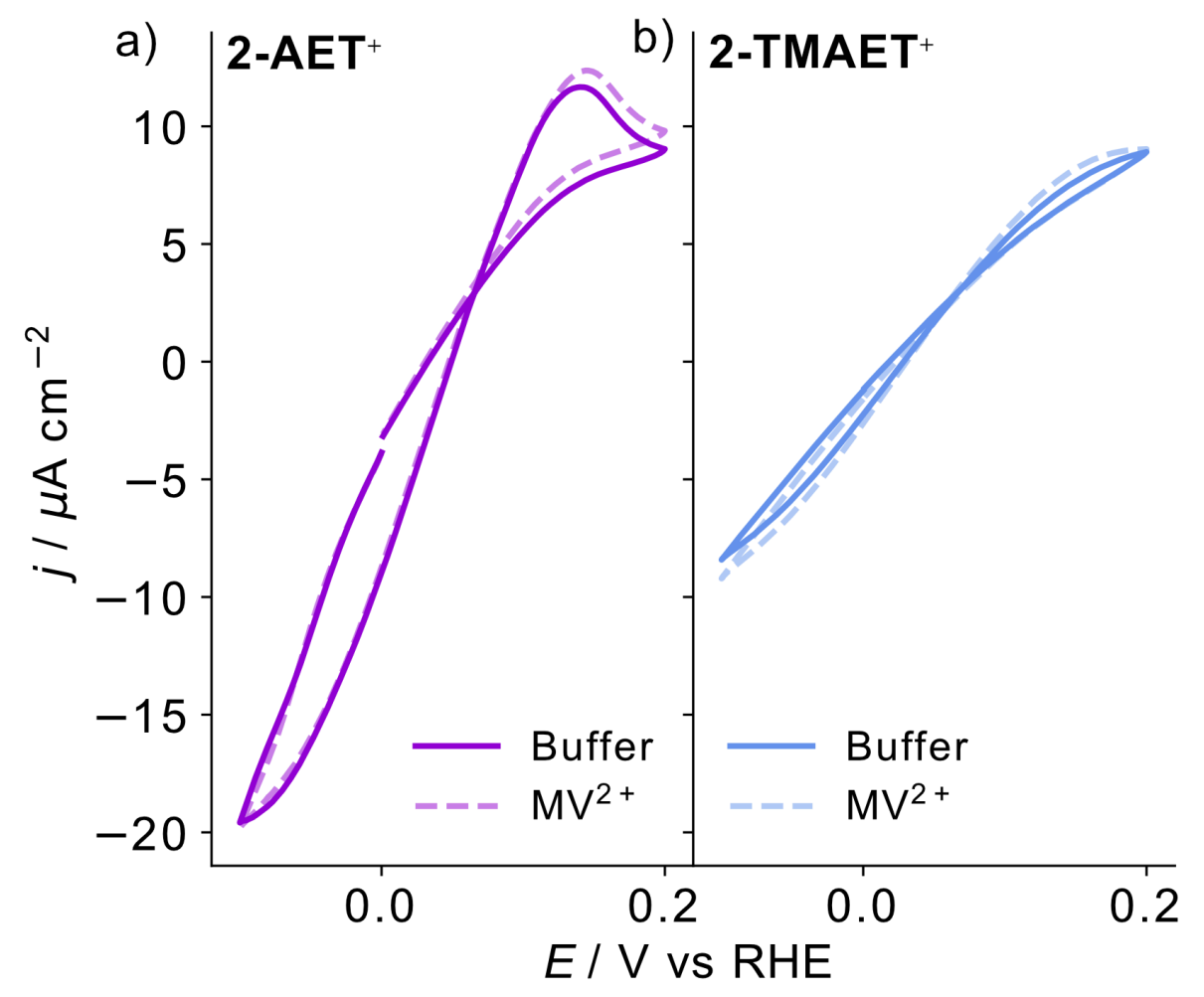

Figure S10. E-QCM PFV responses of $\mathrm{H}_{2}$ ase loaded on (a) 2-AET ${ }^{+}$-modified sensors and (b) 2TMAET $^{+}$-modified sensors before and after the injection of $\mathrm{MV}^{2+}(250 \mu \mathrm{M})$. Conditions: $\mathrm{MES} / \mathrm{KCl}(50 \mathrm{mM} / 50 \mathrm{mM}, \mathrm{pH} 6), 1$ atm $\mathrm{H}_{2}$, flow rate $=0.141 \mathrm{~mL} \mathrm{~min}^{-1}, 25{ }^{\circ} \mathrm{C}$. 


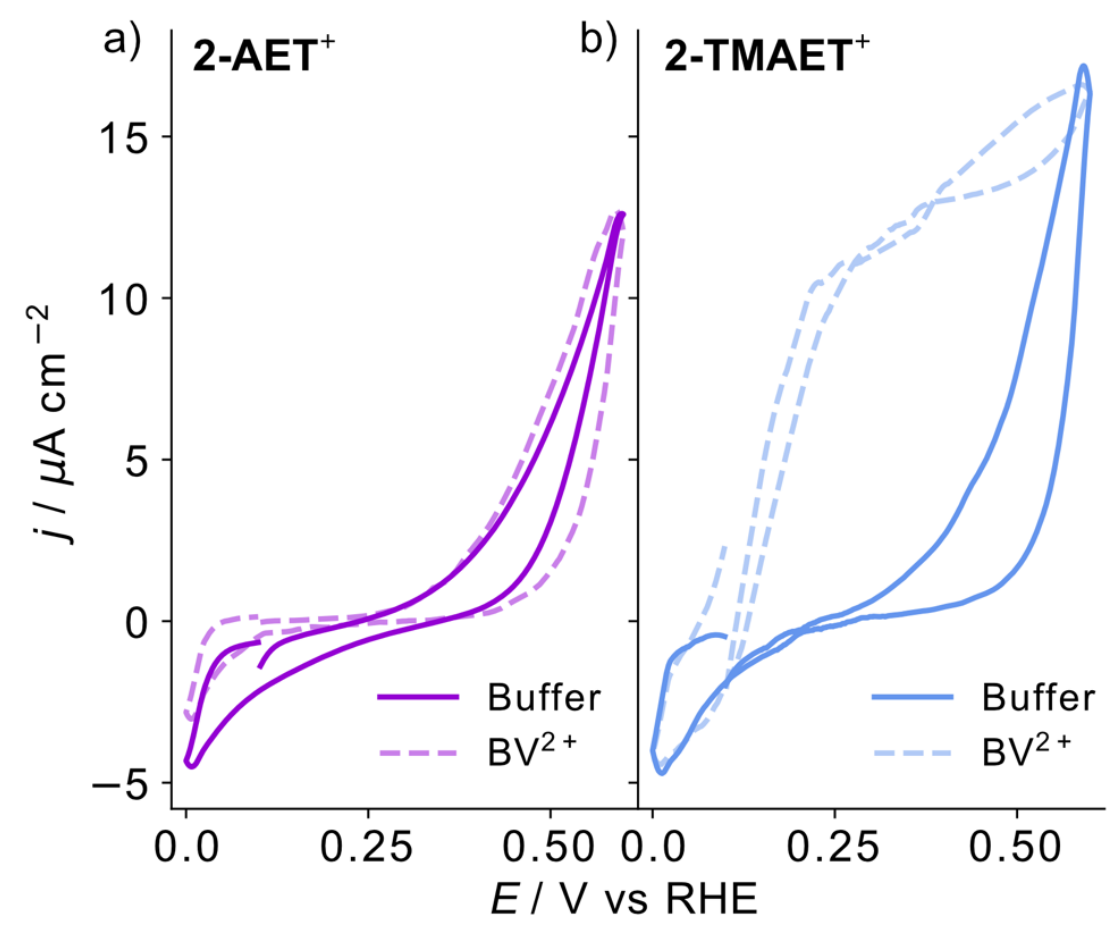

Figure S11. E-QCM PFV responses of FDH loaded on (a) 2-AET ${ }^{+}$-modified sensors and (b) 2$\mathrm{TMAET}^{+}$-modified sensors before and after the injection of $\mathrm{BV}^{2+}(250 \mu \mathrm{M})$. The increase in MET for 2-TMAET ${ }^{+}$at low overpotentials indicates that electron transfer is initially not as optimal as $2-\mathrm{AET}^{+}$, however, at high overpotentials $j_{\mathrm{DET}} / j_{\mathrm{MET}}=1$, indicating possible reorientation at high oxidative overpotentials. Conditions: $\mathrm{HEPES} / \mathrm{KCl} /$ formate $(50 \mathrm{mM} / 50 \mathrm{mM}, \mathrm{pH} 8), 1$ atm $\mathrm{N}_{2}$, flow rate $=0.141 \mathrm{~mL} \min ^{-1}, 25^{\circ} \mathrm{C}$. 
Table S1. Comparisons of solution assay TOFs and electrocatalytic TOFs for redox enzymes immobilized on different electrodes.

\begin{tabular}{|c|c|c|c|c|c|c|c|}
\hline Enzyme $^{a}$ & Electrode $^{b}$ & $\begin{array}{l}\text { Loading } \\
\left(\mathrm{pmol}^{\mathrm{cm}} \mathbf{c m}^{-2}\right)^{c}\end{array}$ & $\begin{array}{l}\text { Solution } \\
\left(\mathbf{s}^{-1}\right)^{d, e}\end{array}$ & $\begin{array}{l}\boldsymbol{E}_{\text {app }}(\mathbf{V} \\
\text { RHE })^{f}\end{array}$ & vs & $\begin{array}{l}\text { Electrode } \\
\left(\mathbf{s}^{-1}\right)^{g}\end{array}$ & Reference \\
\hline W-FDH (Sf) & $\begin{array}{l}\text { Pyrolytic } \\
\text { graphite edge }\end{array}$ & 3.5 & $\begin{array}{l}3,380 \mathrm{~s}^{-1}(+), \\
282 \mathrm{~s}^{-1}(-)\end{array}$ & -0.45 & & $112 \mathrm{~s}^{-1}(\mathrm{DET},-)$ & 17 \\
\hline $\mathrm{W}-\mathrm{FDH}(D v \mathrm{H})$ & SAMIAu & 8.6 & $1144 \mathrm{~s}^{-1}(+)$ & +0.27 & & $20.5 \mathrm{~s}^{-1}(\mathrm{DET},+)$ & 23 \\
\hline $\mathrm{W}-\mathrm{FDH}(D v \mathrm{H})$ & $\begin{array}{l}\text { Functionalised } \\
\text { graphite }\end{array}$ & 106 & $\begin{array}{l}1144 \mathrm{~s}^{-1}(+), \\
236 \mathrm{~s}^{-1}(-)\end{array}$ & $\begin{array}{l}+0.27(+) \\
-0.25(-)\end{array}$ & & $\begin{array}{l}10.2 \mathrm{~s}^{-1}(\mathrm{DET},+) \\
3.5 \mathrm{~s}^{-1}(\mathrm{DET},-) \\
8.6 \mathrm{~s}^{-1}(\mathrm{MET},-)\end{array}$ & 23 \\
\hline $\mathrm{W}-\mathrm{FDH}(D v \mathrm{H})$ & $\begin{array}{l}\text { Gas diffusion } \\
\text { electrode and } \\
\text { redox polymer }\end{array}$ & 650 & $\begin{array}{l}940(+), \\
240 \mathrm{~s}^{-1}(-)\end{array}$ & $-0.24(-)$ & & $\begin{array}{l}1.7(\mathrm{DET},-) \\
2.8(\mathrm{MET},-)\end{array}$ & 77 \\
\hline $\mathrm{W}-\mathrm{FDH}(D v \mathrm{H})$ & mesoITO & 170 & $\begin{array}{l}1100 \mathrm{~s}^{-1}(+), \\
320 \mathrm{~s}^{-1}(-)\end{array}$ & $-0.22(-)$ & & $3 \mathrm{~s}^{-1}(\mathrm{DET},-)$ & 54 \\
\hline $\mathrm{W}-\mathrm{FDH}(D v \mathrm{H})$ & IO-ITO & 104 & $\begin{array}{l}1100 \mathrm{~s}^{-1}(+), \\
320 \mathrm{~s}^{-1}(-)\end{array}$ & $-0.53(-)$ & & $42 \mathrm{~s}^{-1}(-)$ & 79 \\
\hline $\begin{array}{l}{[\mathrm{NiFeSe}]-\mathrm{H}_{2} \text { ase }} \\
(D v \mathrm{H})\end{array}$ & IO-ITO & 50 & $8272 \mathrm{~s}^{-1}(-)$ & $-0.50(-)$ & & $95 \mathrm{~s}^{-1}(-)$ & 9 \\
\hline
\end{tabular}




\begin{tabular}{lllllll}
\hline$[\mathrm{NiFeSe}]-\mathrm{H}_{2}$ ase & IO-ITO & 80 & $8700 \mathrm{~s}^{-1}(+)$, & $-0.25(-)$ & $25 \mathrm{~s}^{-1}(-)$ & 37 \\
$(\mathrm{Dmb})$ & & $2933 \mathrm{~s}^{-1}(-)$ & & \\
& & & & & \\
\hline BOD $(M v)$ & SAMIAu & 4.2 & $115 \mathrm{~s}^{-1}(-)$ & $+0.55(-)$ & $35 \mathrm{~s}^{-1}(-)$ & 25,72
\end{tabular}

asf: Syntrophobacter fumaroxidans. DvH: Desulfovibrio vulgaris Hildenborough. Dmb: Desulfomicrobium baculatum. Mv: Myrothecium verrucaria.

bmeso: mesoporous. IO: Inverse opal. SAM: Self-assembled monolayer.

'Enzyme loading measured by QCM, surface plasmon resonance or estimated from total amount of enzyme drop-cast on the electrode.

${ }^{\mathrm{d}}$ The solution TOFs refer to the activity of the enzymes as measured by solution assays. For BOD, the activity is given in units mg ${ }^{-1}$ (1 $\mathrm{U}$ $\mathrm{mg}^{-1}=1 \mu \mathrm{mol} \mathrm{min}^{-1} \mathrm{mg}^{-1}$, ChemPhysChem 2013, 14, $2097-2100$ ), which is converted to $\mathrm{s}^{-1}$ by using the enzyme molecular mass of $244.45 \mathrm{kDa}$.

${ }^{e}(+)$ signifies the activity values for the relevant oxidation reaction (formate oxidation or $\mathrm{H}_{2}$ oxidation). (-) signifies the activity values for the relevant reduction reaction $\left(\mathrm{CO}_{2}\right.$ reduction, $\mathrm{H}^{+}$reduction).

${ }^{\mathrm{f}} E_{\text {app }}$ is taken either from chronoamperometry or from a set potential at which a current was used to measure the TOF.

${ }^{\mathrm{g}}$ Electrode TOF is calculated from either the current and loading using eq 2 in the Experimental Section or by product quantification.

End of Supporting Information 